\title{
SORTING AND SELECTIVE MOVEMENT OF SEDIMENT ON COAST WITH STEEP SLOPE- MASUREMENTS AND PREDICTION
}

\author{
Toshiro San-nami ${ }^{1}$, Takaaki $\mathrm{Uda}^{2}$, Masumi Serizawa ${ }^{1}$ and Toshinori Ishikawa ${ }^{2}$
}

\begin{abstract}
"Conveyer belts" carrying gravel and fine sand have developed on the Shimizu coast. After the construction of an Lshaped groin to protect the Hagoromo-no-matsu sandy beach located at the northern part of the Shimizu coast, these conveyer belts split into two, inducing longshore and offshore transport, because the seabed topography markedly changes and submarine canyons with a steep offshore slope develop immediately north of the L-groin. Coarse material is transported alongshore and fine material is discharged offshore. Material movement is investigated on the basis of bathymetric survey data and the depth distribution of the grain size of the seabed material. The effect of extending four breakwaters to control the movement of gravel and to stabilize the shoreline downcoast of the L-groin is predicted using the contour-line-change model. The optimum arrangement of breakwaters, along with beach nourishment, is numerically predicted.
\end{abstract}

Keywords: Shimizu coast; beach changes; beach nourishment; measure against beach erosion; contour-line-change model

\section{INTRODUCTION}

Beach erosion has been severe on the Shimizu coast, which extends along the outer marginal coastline of the Mihono-Matsubara sand spit in Suruga Bay, as shown in Fig. 1, because of the decrease in longshore sand supply from the Abe River (Nishitani et al., 2008). As a measure against beach erosion, five sets of artificial headlands and an L-shaped groin (L-groin) were constructed between 1989 and 1999. At present, the shoreline of this coast is barely maintained by these facilities and beach nourishment. Analysis based on bathymetric surveys of this coast and bottom-sampling data suggests that there are two "conveyer belts" carrying gravel and fine sand along the coastline and that these conveyer belts have been disrupted by the construction of the coastal structures. Nishitani et al. (2008) analyzed the mechanism of the development and deformation of these conveyer belts through a field investigation and a numerical simulation using the contour-line-change model (Serizawa et al., 2003). Although these conveyer belts continue to develop downcoast of the L-groin, they split into two, inducing longshore and offshore transport, because the seabed topography markedly changes and submarine canyons with a steep offshore slope have developed immediately north of the L-groin. Gravel is transported alongshore and fine sand is discharged offshore, causing a loss of sand. In this study, these features are investigated on the basis of bathymetric survey data and the depth distribution of the grain size of the seabed material. Then, the beach changes around four breakwaters $\left(B_{1}-B_{4}\right)$ constructed to stabilize the shoreline downcoast of the L-groin (LG) are predicted using the contourline-change model.

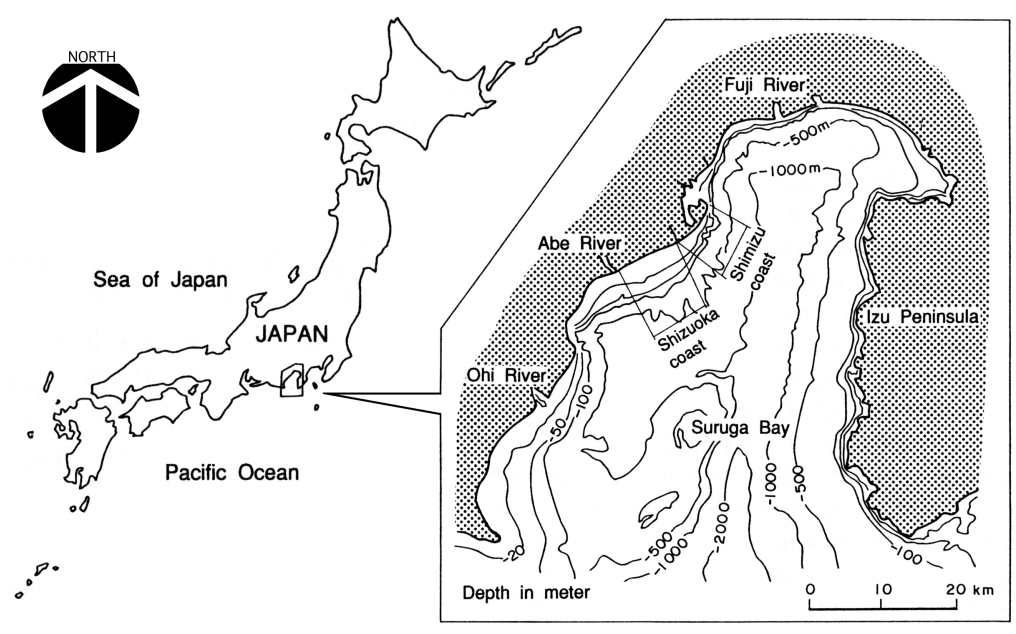

Figure 1. Location of Shimizu coast.

\footnotetext{
${ }^{1}$ Coastal Engineering Laboratory Co., Ltd., 301, 1-22 Wakaba, Shinjuku, Tokyo 160-0011, Japan

${ }^{2}$ Public Works Research Center, 1-6-4 Taito, Taito, Tokyo 110-0016, Japan
} 

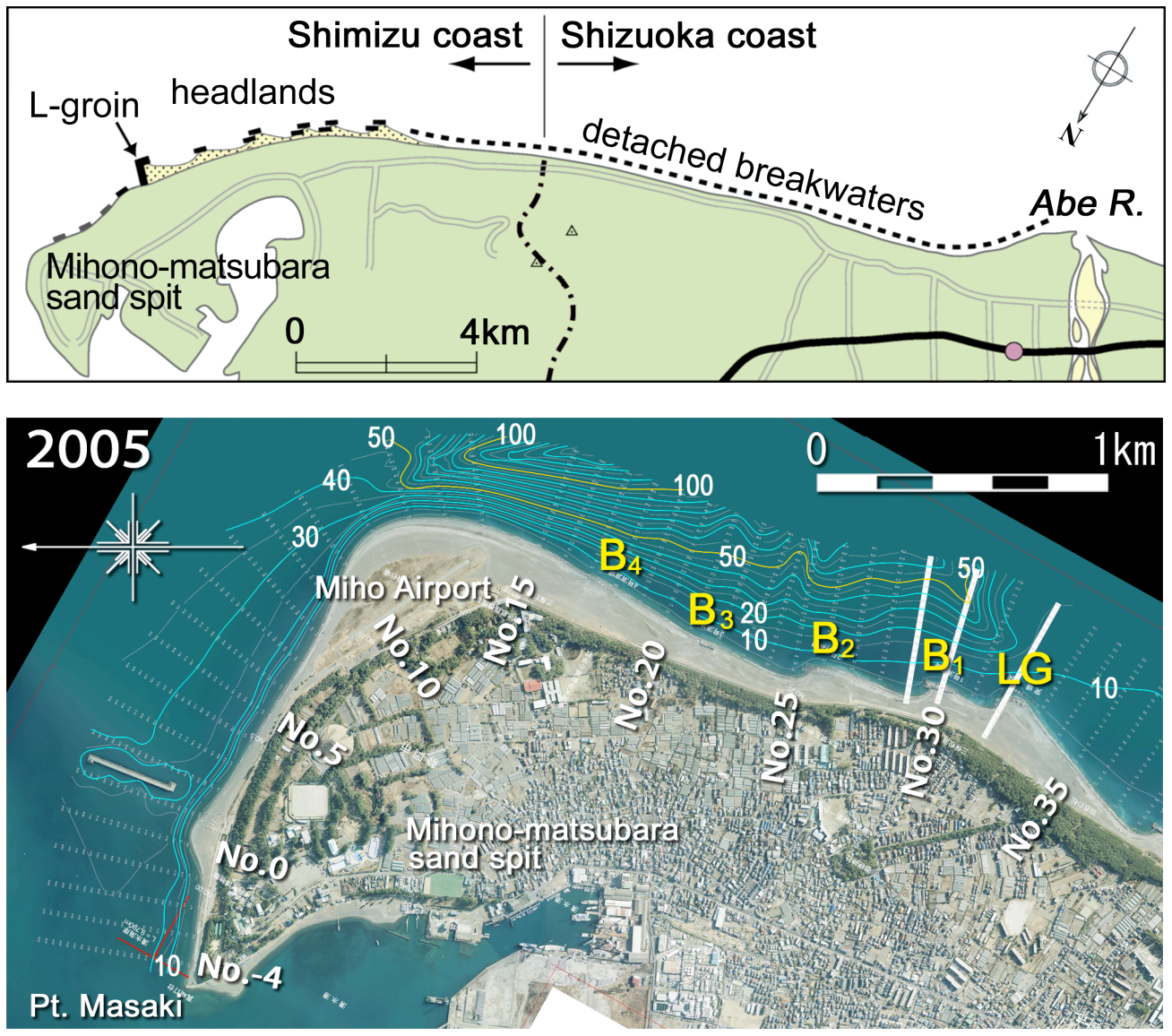

Figure 2. Location of Shimizu coast and alignment of transects.

\section{CHANGES IN LONGITUDINAL PROFILES AND GRAIN SIZE}

On the basis of topographic survey data taken since 1985 at $200 \mathrm{~m}$ intervals along the shoreline, the changes in longitudinal profile were investigated along eight transects between No. 32, immediately south (upcoast) of the L-groin at the southernmost location of the study area, and No. 25, north of breakwater No. 2, as shown in Fig. 2. Figure 3 shows the change in longitudinal profiles along with the depth distribution of $d_{50}$ of the bed material measured in 2006 .

Along transect No. 32, a large amount of coarse sand and gravel has been deposited in the zone shallower than $-10 \mathrm{~m}$ since 1985, resulting in a shoreline advance of $90 \mathrm{~m}$ up to 2007 because of the blockage of northward longshore sand transport by the L-groin (Fig. 3(a)). Before 2002, the longitudinal profile exhibited a change in slope at a depth of $8 \mathrm{~m}$ with a steep slope of $1 / 4.2$ in the zone shallower than $-8 \mathrm{~m}$ and $1 / 18$ in the offshore zone. However, in 2007 , the change in slope in the longitudinal profile disappeared and a smooth profile was formed between the shoreline and $-10 \mathrm{~m}$ owing to sand deposition in the offshore zone.

Along transect No. 30, which crosses breakwater No. 1, the shoreline had advanced between 1985 and 1995, but the shoreline position has remained fixed since 2002 after the construction of breakwater No. 1 (Fig. 3(b)). Furthermore, gravel with a median diameter $\left(d_{50}\right)$ of $10 \mathrm{~mm}$ has been deposited in the zone shallower than $-5 \mathrm{~m}$, whereas fine sand with a grain size of $d_{50}=0.2 \mathrm{~mm}$ has been deposited in the depth zone between $-7 \mathrm{~m}$ and $-23 \mathrm{~m}$ offshore of the breakwater. Fine sand has been continuously deposited in the offshore zone between 1985 and 2007, and the offshore seabed slope at a $15 \mathrm{~m}$ depth has gradually steepened from $1 / 9$ (1985), to $1 / 8$ (1995), to $1 / 6$ (2002) and to $1 / 5$ (2007). This change in the longitudinal profile and the deposition of fine sand suggest that fine sand transported around the tip of the L-groin is discharged into the offshore zone via the offshore zone of breakwater No. 1.

Along transect No. 29 immediately downcoast of breakwater No. 1, the shoreline advanced between 1985 and 1995, but marked beach erosion started in the zone shallower than $-7 \mathrm{~m}$ after the construction of breakwater No. 1, resulting in shoreline recession of up to $65 \mathrm{~m}$ by 2007 (Fig. 3(c)). Along this transect, fine sand with $d_{50}$ of $0.2 \mathrm{~mm}$ was also continuously deposited in the zone deeper 
than $-10 \mathrm{~m}$, similar to the case along transect No. 30. Thus, in the zone between breakwater No. 1 and a location $100 \mathrm{~m}$ north of the breakwater, fine sand has been deposited and has sunk into the submarine canyons; the deposition zone of fine sand is distributed in the zone deeper than $-10 \mathrm{~m}$.

Taking into account the fact that sand deposition in this area began after the construction of the Lgroin, the littoral zone, where longshore sand transport occurs, is considered to have been pushed offshore because of the extension of the groin, resulting in the discharge of fine sand transported around the tip of the L-groin.

(a)

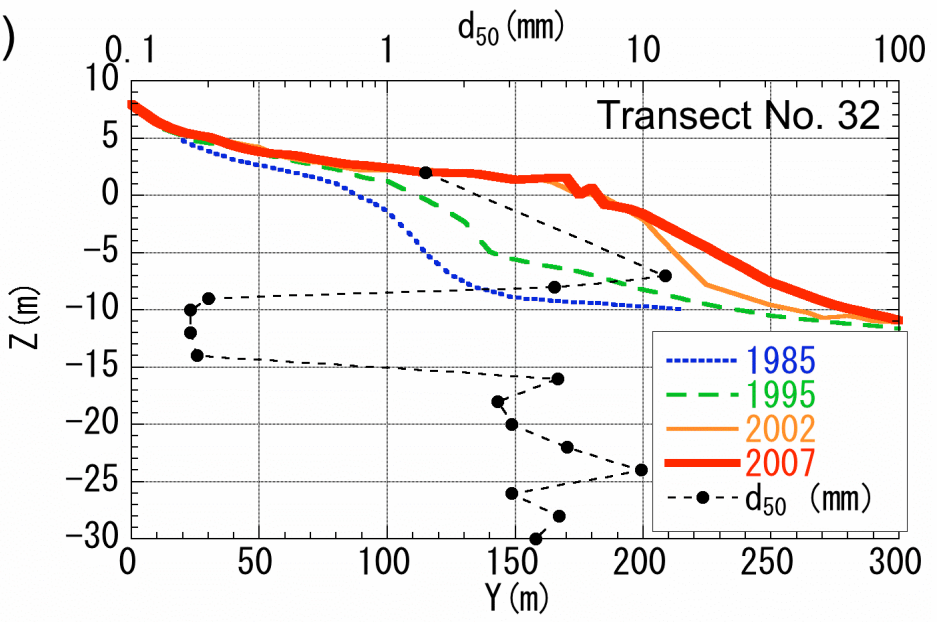

(b)

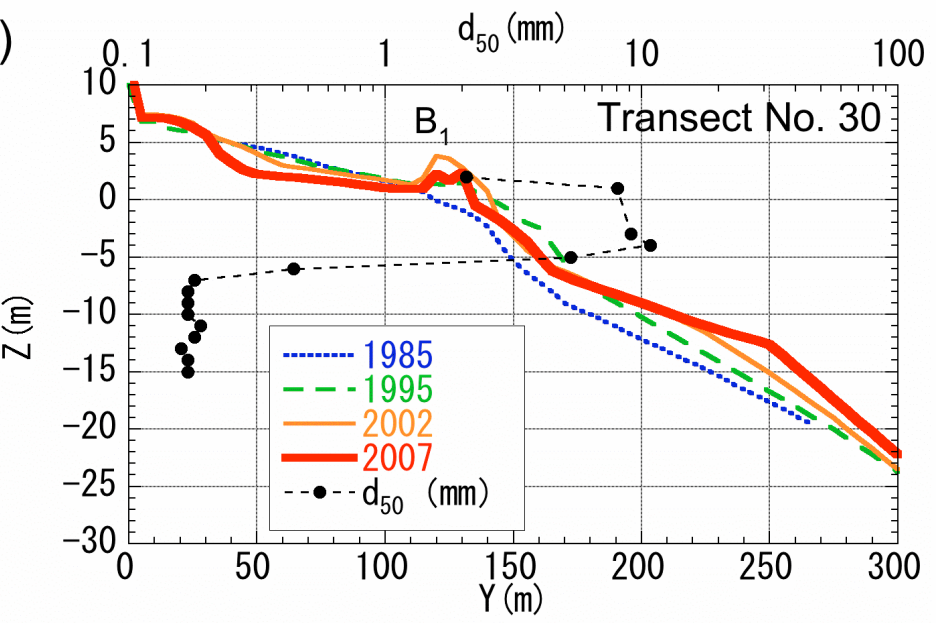

(c)

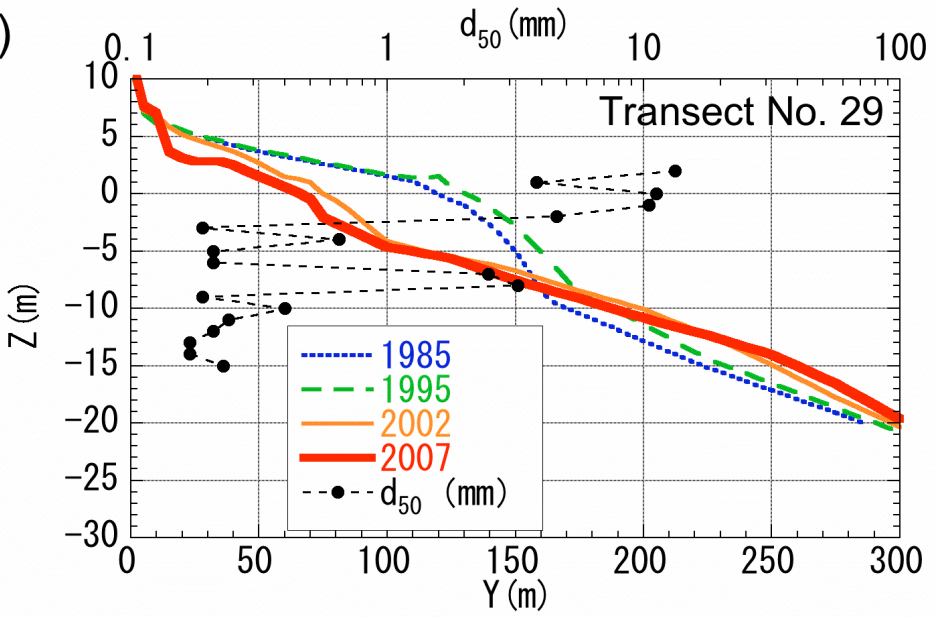

Figure 3. Changes in longitudinal profiles and grain size. 


\section{BATHYMETRIC CHANGES AND CHANGE IN LONGSHORE SAND TRANSPORT}

The bathymetric changes up to 2007, with reference to the bathymetry in 1985, are shown in Fig. 4 along with the bathymetry in 2007. Three features are noted in this figure. First, a large amount of sand was deposited south of the L-groin with a maximum sand deposition of $12 \mathrm{~m}$ thick, whereas the shoreline was heavily eroded north of the L-groin. This is because northward longshore sand transport was blocked by the L-groin. Second, a sand deposition zone extended obliquely offshore from the tip of the L-groin, implying that fine sand with a grain size of $d_{50}=0.2 \mathrm{~mm}$ is being selectively discharged into the submarine canyon. Third, in contrast to the offshore sand transport around the tip of the Lgroin, in the nearshore zone immediately downcoast of breakwaters Nos. 1 and 2, the erosion zone extended northward. The expansion of eroded zones immediately north of the breakwaters was also caused by the blockage of longshore sand transport by the breakwaters.

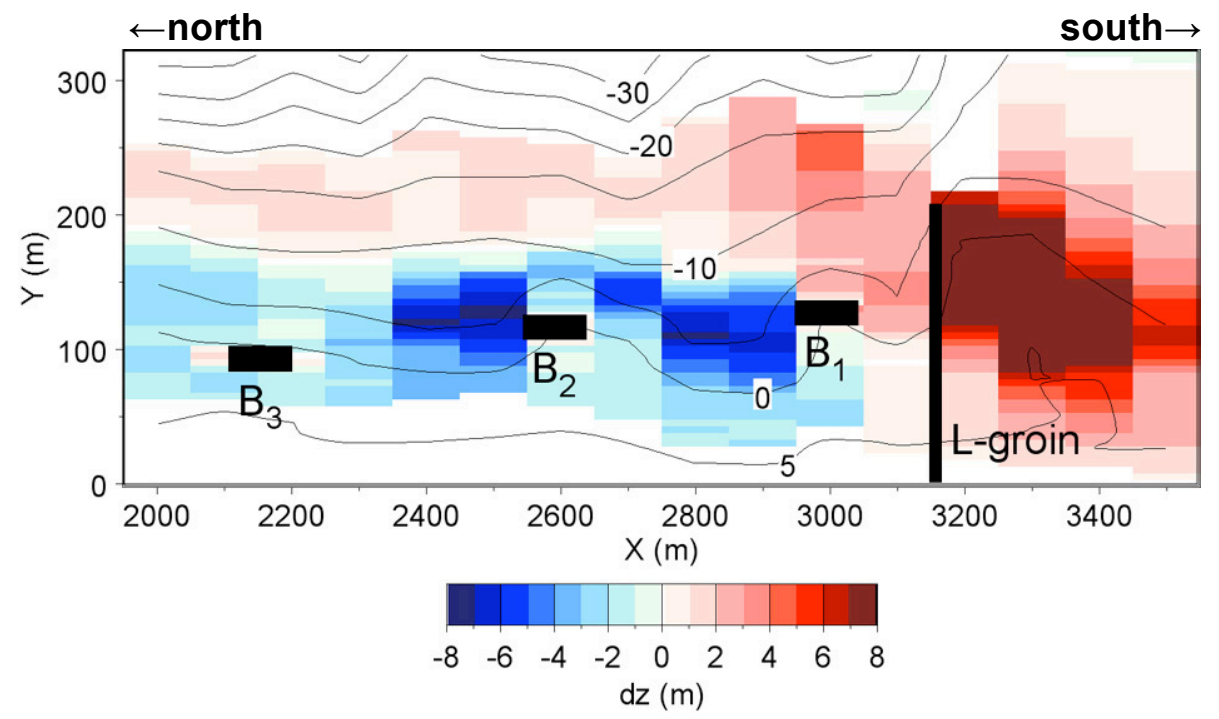

Figure 4. Bathymetric changes between 1985 and 2007.

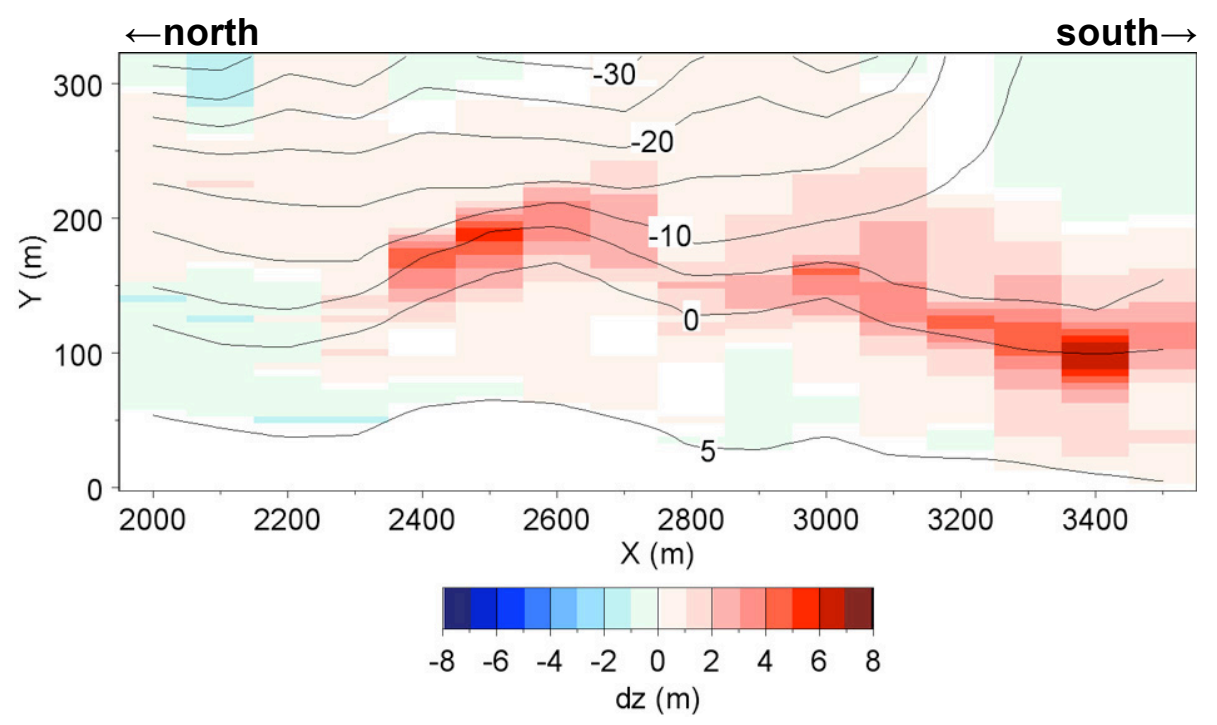

Figure 5. Bathymetric changes between 1990 and 1995.

The bathymetric changes were investigated at five year intervals. Figure 5 shows the bathymetric changes between 1990 and 1995. A small amount of sand was deposited along the shoreline in a wide area south of $X=2400 \mathrm{~m}$ during this period, but large changes did not occur. Regarding the bathymetric 
changes between 1995 and 2001, however, sand began to be deposited south of the L-groin after its construction, whereas erosion started north of the L-groin. In particular, severe beach erosion occurred immediately north of breakwater No. 1, as shown in Fig. 6. Then, concerning the bathymetric changes between 2001 and 2007, as shown in Fig. 7, sand deposition south of the L-groin ceased and the erosion zone moved northward compared with its location in Fig. 6. The extent of erosion decreased in the zone immediately north of breakwater No. 1, where severe erosion was observed in Fig. 6, and instead, severe beach erosion occurred in the zone immediately north of breakwater No. 2. Thus, the erosion zone expanded northward over time.

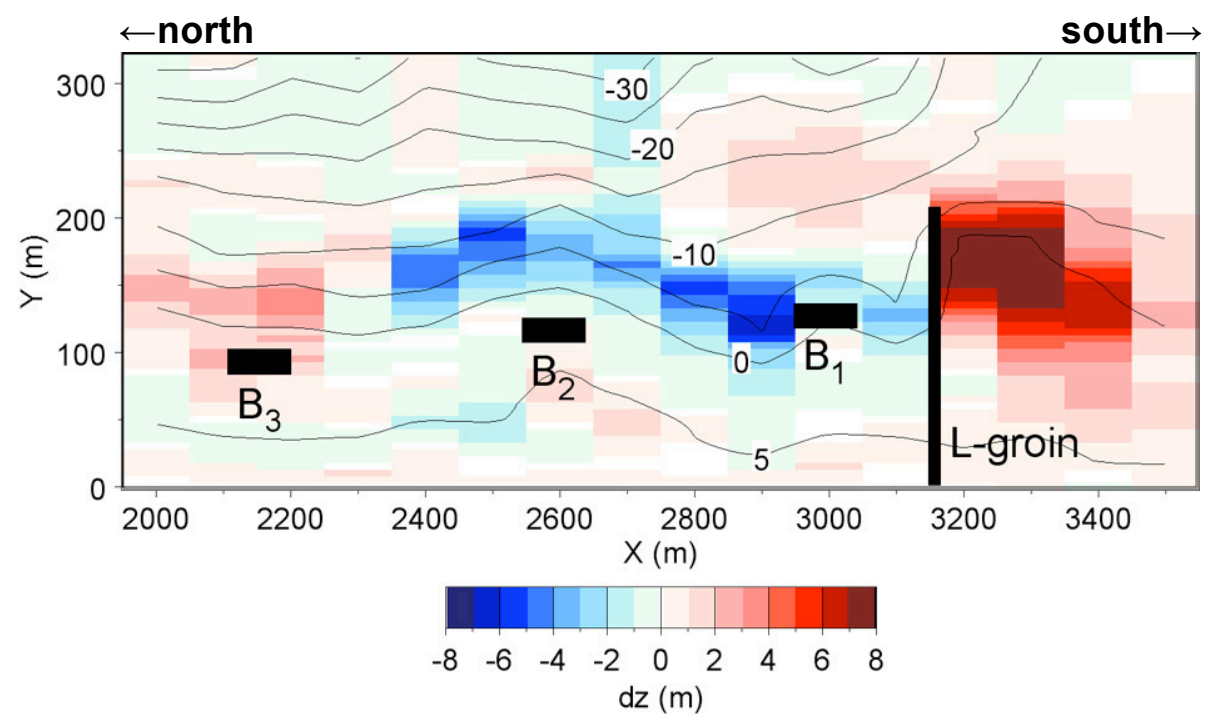

Figure 6. Bathymetric changes between 1995 and 2001.

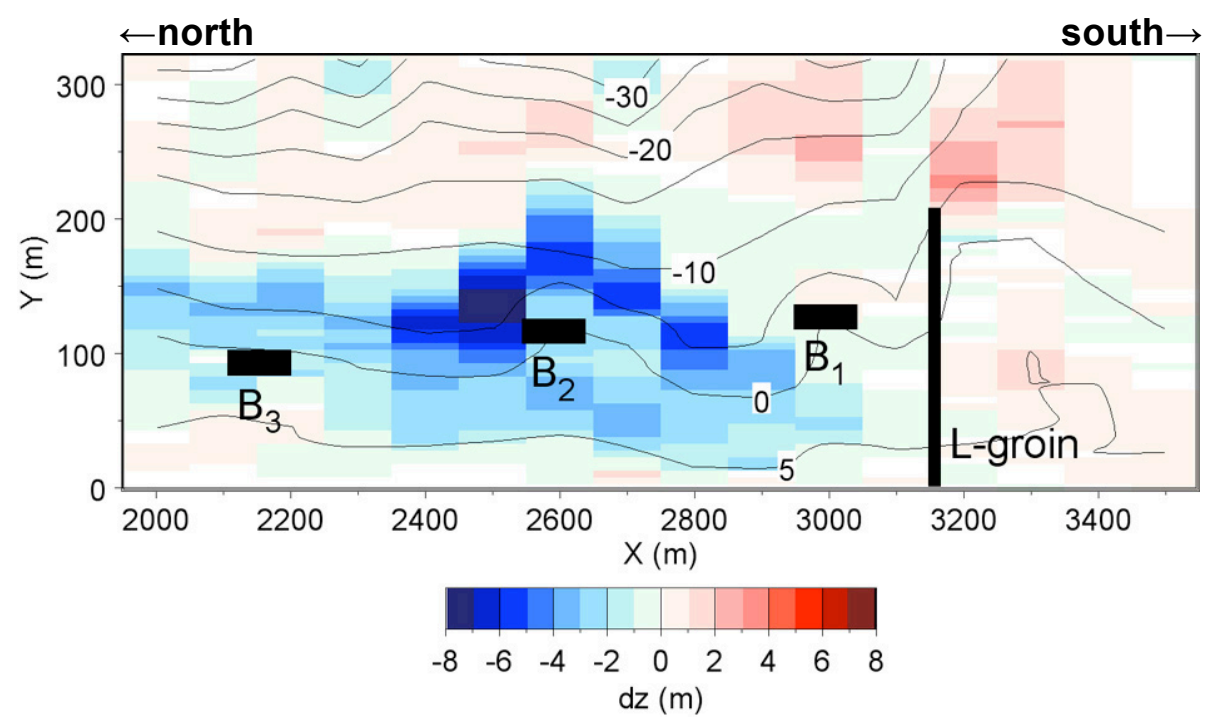

Figure 7. Bathymetric changes between 2001 and 2007.

The distribution of longshore sand transport is estimated by integrating the change in sand volume between Point Masaki, located at the tip of the sand spit, and the L-groin, on the basis of the bathymetric survey data between 1998 and 2006, assuming that the longshore sand transport passing through Point Masaki is negligible. Figure 8 shows the distribution of longshore sand transport. Longshore sand transport between the L-groin and breakwater No. 1 is slight at approximately $0.7 \times 10^{4}$ $\mathrm{m}^{3} / \mathrm{yr}$, but it increases rapidly toward breakwater No. 3 to reach $7.5 \times 10^{4} \mathrm{~m}^{3} / \mathrm{yr}$. 


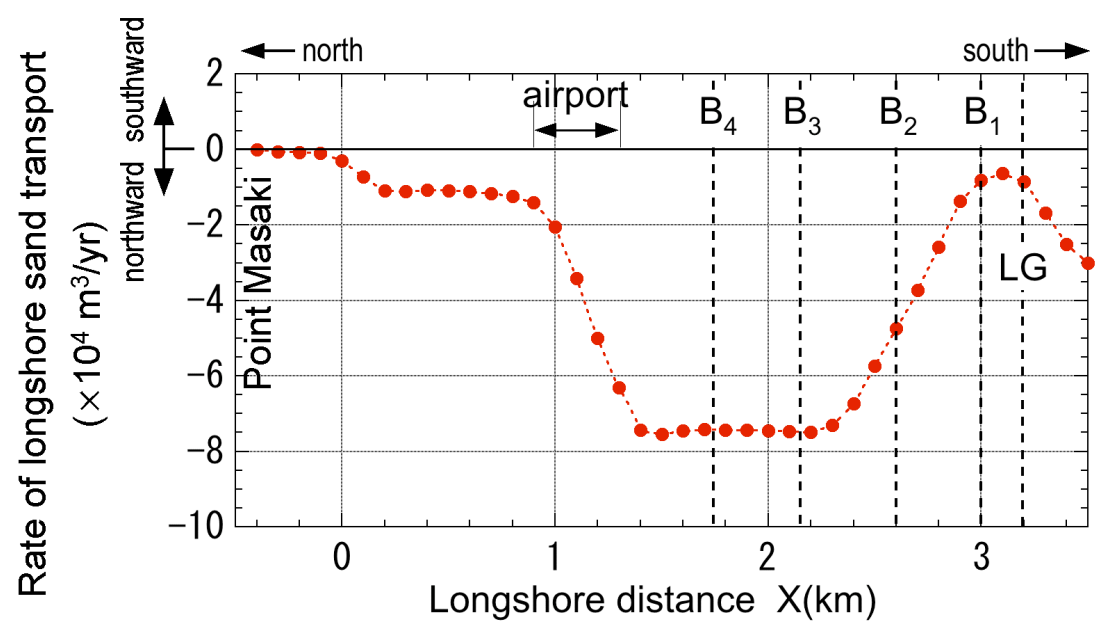

Figure 8. Distribution of longshore sand transport.

\section{NUMERICAL SIMULATION OF BATHYMETRIC CHANGES IN NEARSHORE ZONE}

Although fine sand was transported near the tip of the L-groin toward the submarine canyon, as shown in Fig. 4, beach changes also occurred north (downcoast) of the L-groin in the zone shallower than approximately $-10 \mathrm{~m}$. These changes are considered to be caused by the spatial imbalance of the transport of coarse sand and gravel upon considering the grain size distribution shown in Fig. 3. Such beach changes in the nearshore zone may be predicted using the contour-line-change model with a single grain size and the corresponding equilibrium slope proposed by Serizawa et al. (2003). Therefore, the bathymetric changes along the coast with a steep slope and $1.4 \mathrm{~km}$ stretch between the L-groin and breakwater No. 4 were predicted using the contour-line-change model, along with the investigation of the effect of elongating the existing breakwaters as a measure against beach erosion. Table 1 shows the calculation conditions.

\begin{tabular}{|c|c|}
\hline Initial bathymetry & Straight parallel contours using expanded coordinates \\
\hline Wave conditions & $\begin{array}{l}\text { Equivalent wave height } H_{0}{ }^{\prime}=3 \mathrm{~m} \text {, wave period } T=9_{\mathrm{s}} \text {, wave direction } \\
\theta_{w}=20^{\circ}\end{array}$ \\
\hline Tide condition & Mean sea level \\
\hline Depth of closure and berm height & $h_{c}=12 \mathrm{~m}$ and $h_{R}=3 \mathrm{~m}$ \\
\hline Coefficient of sand transport & $\begin{array}{l}K_{x}=0.0022, K_{z}=0.1 K_{x} \\
K_{2}=1.62 K_{x}(\text { Ozasa and Brampton, } 1980)\end{array}$ \\
\hline $\begin{array}{l}\text { Depth distribution of longshore and } \\
\text { cross-shore sand transport }\end{array}$ & Cubic equation given by Uda and Kawano (1996) \\
\hline Equilibrium slope & $\tan \beta_{c}=1 / 8$ \\
\hline Critical slope on land and sea bottom & $1 / 2$ and $1 / 3$ \\
\hline Calculation range of depth & $z=+3.5 \mathrm{~m}$ to $-12.5 \mathrm{~m}$ \\
\hline Mesh size & $\Delta x=20 \mathrm{~m}$ and $\Delta z=1 \mathrm{~m}$ \\
\hline Time step & $\Delta t=10 \mathrm{hr}$ \\
\hline Boundary conditions of sand transport & $\begin{array}{l}Q_{\text {in }}=7.5 \times 10^{4} \mathrm{~m}^{3} / \mathrm{yr} \text { before } 1998, d Q / d x=0 \text { at left boundary } \\
Q_{\text {in }}=0.7 \times 10^{4} \mathrm{~m}^{3} / \mathrm{yr} \text { after } 1998 \\
Q_{z}=0 \text { at shoreward and seaward ends }\end{array}$ \\
\hline Calculation method & Explicit finite difference method \\
\hline Calculation of wave field & $\begin{array}{l}\text { Angular spreading method for irregular waves (Sakai et al., 2006), } \\
S_{\max }=25\end{array}$ \\
\hline $\begin{array}{l}\text { Wave transmission coefficient of } \\
\text { breakwater }\end{array}$ & $K_{t}=0.4$ \\
\hline
\end{tabular}


In the calculation, the applicability of the model is confirmed by the calculation to reproduce the measured bathymetric changes between 1998 and 2006, and the effect of elongating the existing breakwaters during the 10 years after their construction was compared. In the reproduction, the bathymetry in 1998 before the erosion was transformed into a model coast with straight parallel contours and a slope of $1 / 8$ by expanding the coordinate system (Nishitani et al., 2008). From the assumption that this initial topography was in a dynamic equilibrium under the condition of a supply of $7.5 \times 10^{4} \mathrm{~m}^{3} / \mathrm{yr}$ of sand supply from the upcoast boundary (Nishitani et al., 2008), we assumed that this longshore sand supply in 1998 is reduced to $0.7 \times 10^{4} \mathrm{~m}^{3} / \mathrm{yr}$ after 1998 owing to the extension of the Lgroin, as shown in Fig. 8.

As the wave conditions, rough waves with a $5 \%$ probability of occurrence were selected on the basis of the results of wave observation off the Shimizu coast, because beach changes are more significantly affected by rough waves than by normal waves. The equivalent wave height $H_{0}$ ' and the wave period were selected to be $3 \mathrm{~m}$ and $9 \mathrm{~s}$, respectively. Assuming that waves are incident from the direction normal to the shoreline upcoast of the L-groin, the breaker angle becomes $\theta_{w}=20^{\circ}$ by the wave refraction calculation with Snell's Law. The depth of closure and the berm height were set to be $12 \mathrm{~m}$ and $3 \mathrm{~m}$, respectively, on the basis of measured profile changes. The equilibrium slope was assumed to be the same as the longitudinal slope of $1 / 8$ measured in 1985 .

In the study area, three breakwaters with a $100 \mathrm{~m}$ length have been constructed. In the prediction, we considered ten cases in which the breakwaters are extended northward or southward by $50 \mathrm{~m}$ or 100 $\mathrm{m}$, or a new breakwater is constructed between the existing breakwaters with/without beach nourishment, while changing the direction of extension of the breakwaters, the length and their locations.

\section{RESULTS OF NUMERICAL SIMULATION}

Figure 9 shows the bathymetry in dynamical equilibrium, in which longshore sand transport is supplied from the south (right) boundary at a rate of $7.5 \times 10^{4} \mathrm{~m}^{3} / \mathrm{yr}$ and the same amount of sand is transported away from the north boundary. Given the bathymetry shown in Fig. 9 as the initial condition, the predicted results up to 2006, after longshore sand supply from the upcoast had been reduced to $0.7 \times 10^{4} \mathrm{~m}^{3} / \mathrm{yr}$ since 1998 , are shown in Fig. 10. As a result of the decrease in northward longshore sand transport, the eroded zone extends northward from immediately north of the L-groin. Severe beach erosion occurs around breakwater No. 1, located in the southern part of the study area, and the shoreline significantly retreats. However, the shoreline near breakwater No. 3 in the north part of the study area remains extended straight.

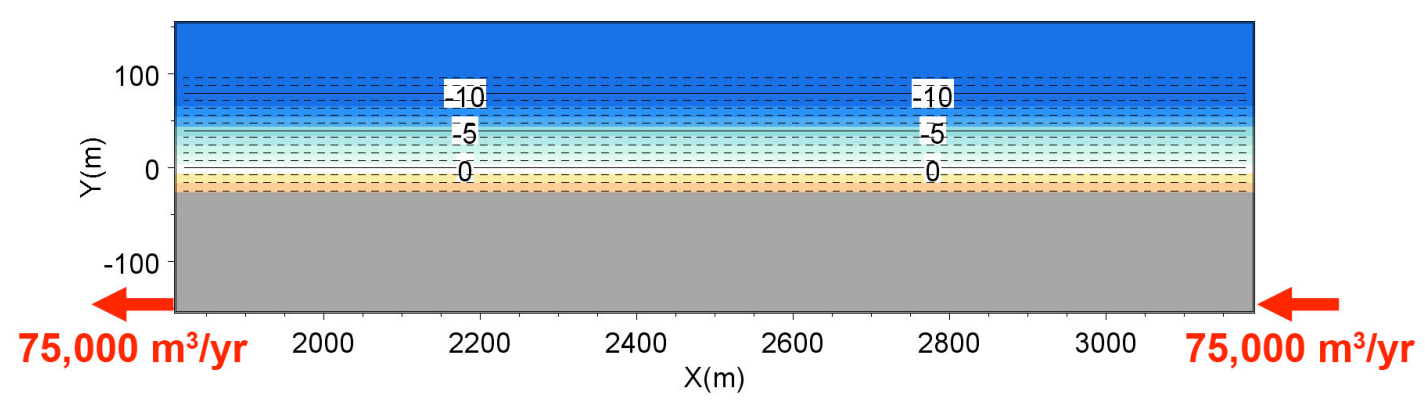

Figure 9. Initial bathymetry in 1998.

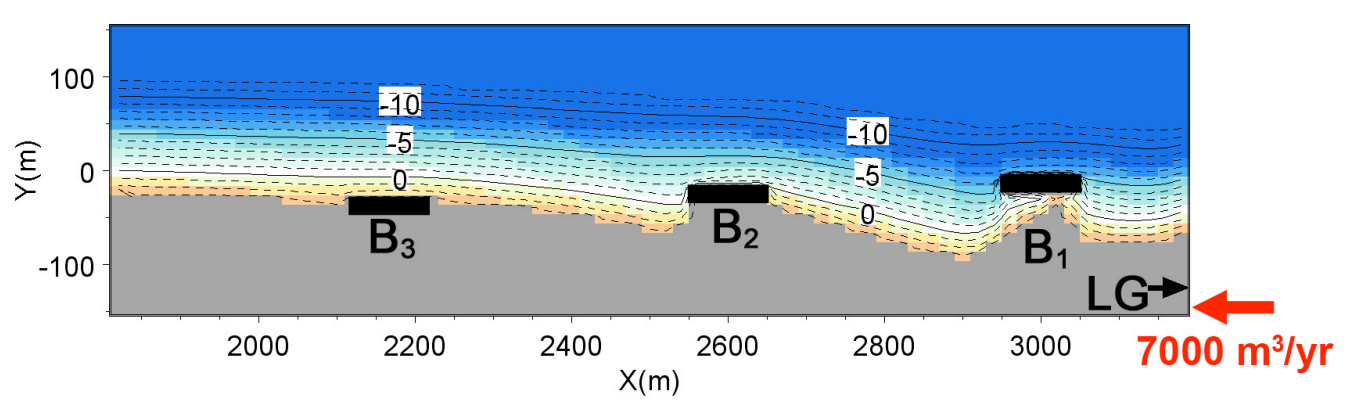

Figure 10. Predicted bathymetry in 2006. 


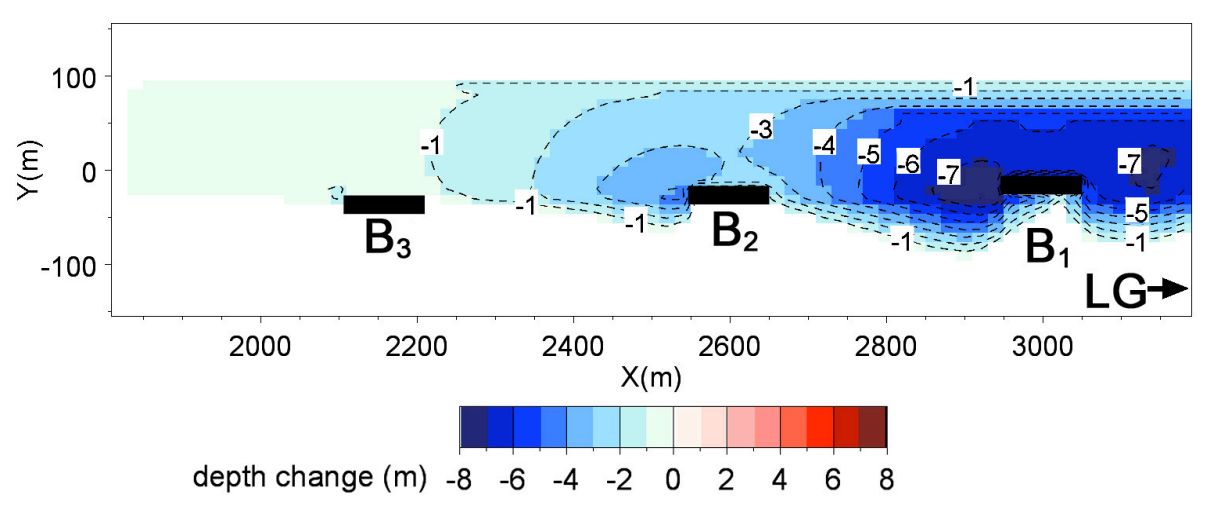

Figure 11. Bathymetric changes between 1998-2006.

Figure 11 shows the planar distribution of bathymetric changes between 1998 and 2006. Severe beach erosion occurred immediately north of the L-groin and breakwater No. 1, and the maximum decrease in ground level was as large as $7 \mathrm{~m}$.

The measured and predicted shorelines are shown in Fig. 12. Although the shoreline recession between the L-groin and breakwater No. 1 was slightly overestimated and that between breakwater Nos. 2 and 3 was underestimated, the overall shoreline changes obtained by measurement and prediction are in good agreement. In fact, although it took 2 years to build the L-groin and breakwaters, these structures were installed from the beginning in the calculation, resulting in a reduction of longshore sand transport. This is considered to be the reason for the discrepancy between the measured and predicted shoreline changes. Because the measured bathymetric changes were accurately reproduced, as described above, the bathymetric changes in cases when various measures were adopted were predicted and compared with the case without any measure.

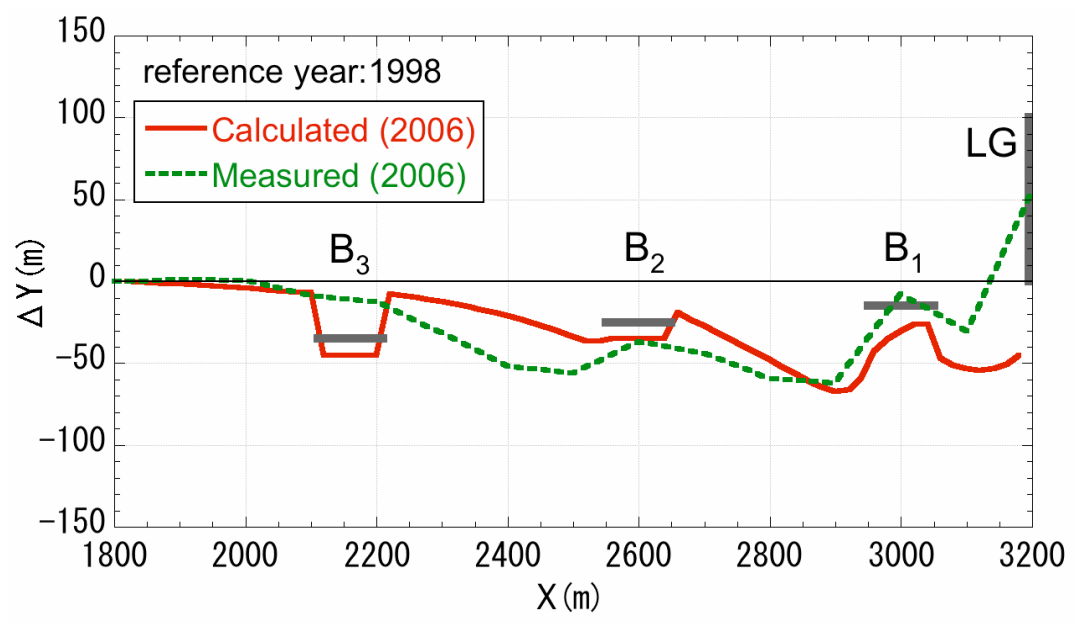

Figure 12. Comparison of shoreline changes.

\section{PREDICTED BATHYMETRY OF EACH CASE AND COMPARISON}

The bathymetric changes between the predicted bathymetry in each case after ten years and the present bathymetry, which was numerically reproduced, were calculated, as shown in Figs. 13 and 14. In case 1 , the present condition remained unchanged without any measures, and the effect of each case can be investigated in comparison with the result of case 1 . In cases 2 and 3, in which breakwater Nos. 1 and 2 are extended northward, sand is deposited behind the breakwater in each case, but the erosion is intensified with the northward movement of the erosion zone. In particular, erosion is severe in case 3 , in which the breakwater is extended by $100 \mathrm{~m}$. In cases 4 and 5, in which breakwaters Nos. 2 and 3 are extended southward while breakwater No. 1 remains as is, sand deposition is enhanced south of the extended breakwater, in contrast with the fact that the northward extension of the breakwater was ineffective. In case 6, in which breakwater Nos. 1 and 3 are extended northward and southward, 
respectively, while breakwater No. 2 remains as is, the extension of breakwater No. 3 is effective for sand deposition, but the extension of breakwater No. 1 causes an adverse effect.
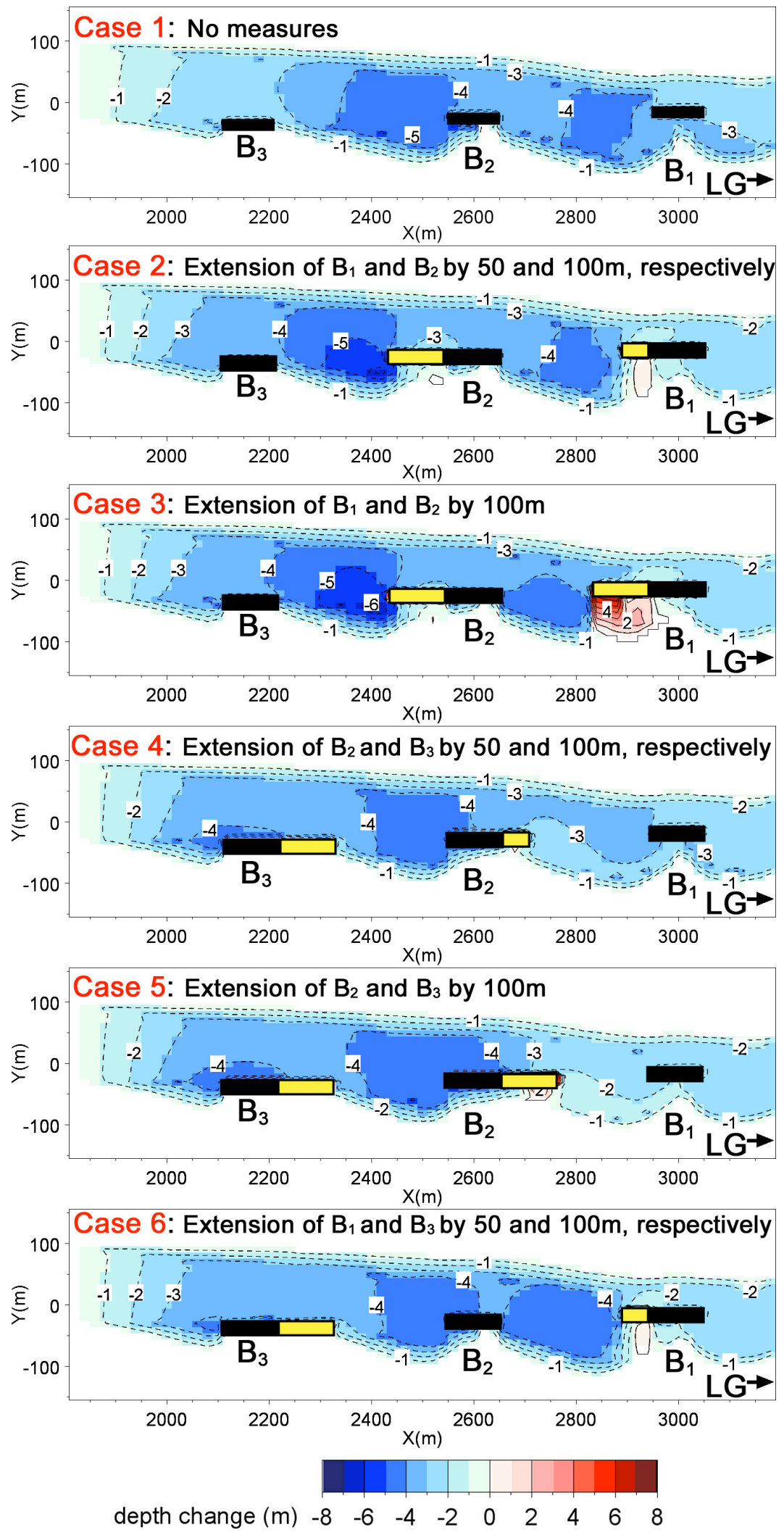

Figure 13. Predicted bathymetry of each case and comparison (case 1-6). 
The effectiveness of the combination of the extension of the existing breakwater with beach nourishment was investigated. In case 7 , in which beach nourishment is carried out at a rate of $6.2 \times 10^{4}$ $\mathrm{m}^{3} / \mathrm{yr}$, the same amount of longshore sand transport at the site in case 1, erosion can almost be prevented, indicating a nourishment effect. However, it is considered to be unrealistic for such an amount of sand to be supplied continuously, so that beach nourishment at a rate of $2 \times 10^{4} \mathrm{~m}^{3} / \mathrm{yr}$ was considered in cases 9 and 10 in addition to the extension of the breakwater examined in cases 4 and 5 . Furthermore, for comparison, bathymetric changes were also predicted in case 8 for case 1 when beach nourishment is carried out at a rate of $2 \times 10^{4} \mathrm{~m}^{3} / \mathrm{yr}$.

Comparing the results of cases 9 and 10 with that of case 8 , in which only beach nourishment is carried out, erosion was mitigated in cases 9 and 10 south of the area where the breakwater was extended. In particular, not only was erosion mitigated, but the upcoast sandy beach was also recovered in case 10, in which the breakwater was extended $100 \mathrm{~m}$ from the south end of breakwater No. 2. However, at the same time, beach erosion was slightly intensified in the north part of breakwater No. 2.

In conclusion, the northward (downdriftward) extension of the breakwater is ineffective for mitigating beach erosion. In contrast, with the southward (updriftward) extension of the breakwater, some effect can be expected in all cases. Of the six cases in which bathymetric changes have been predicted, cases 4 and 5, in which breakwaters Nos. 2 and 3 are extended southward, have an advantage compared with other cases.
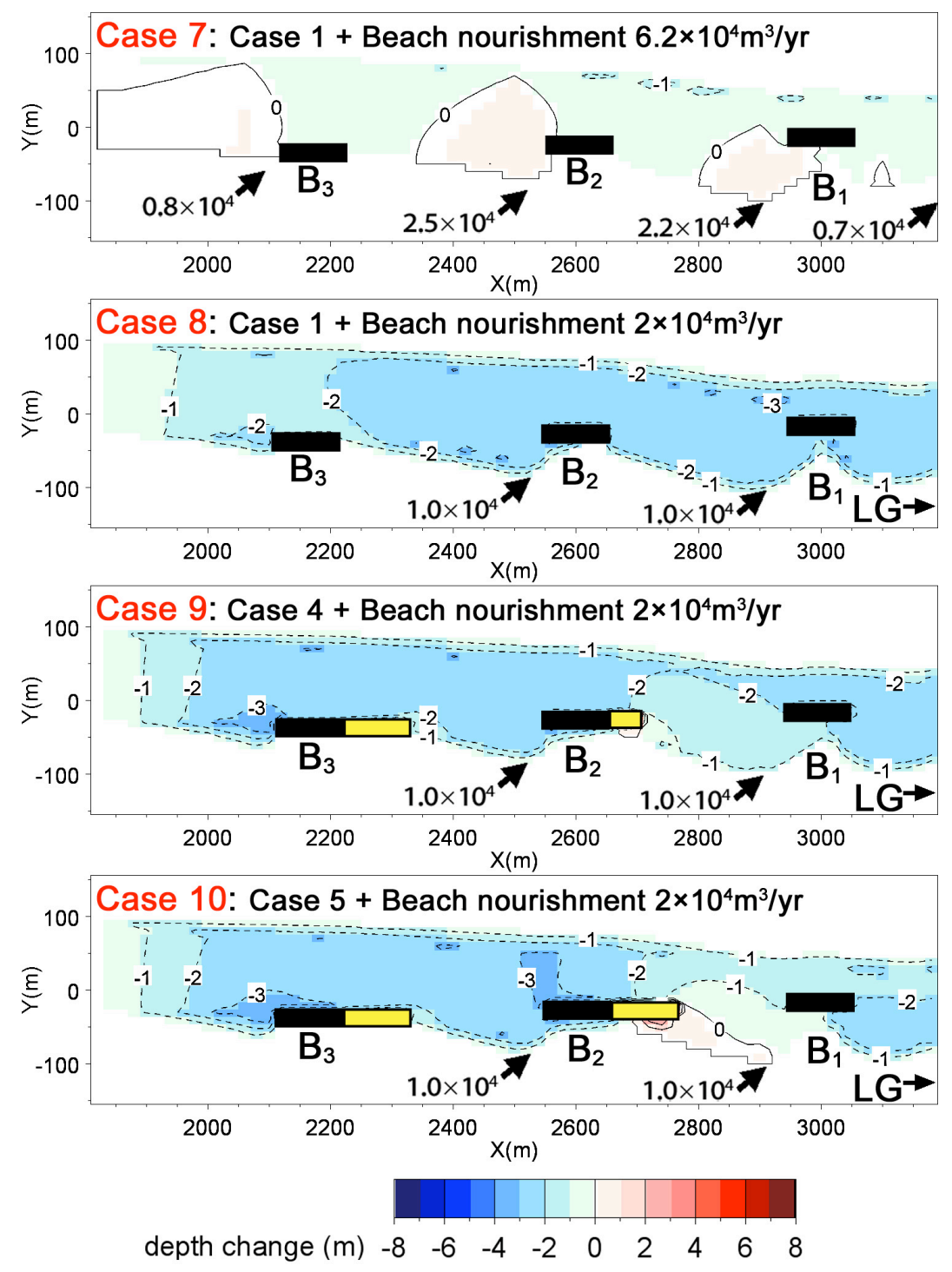

Figure 14. Predicted bathymetry of each case and comparison (case 7-10). 
In short, both the southward extension of the breakwater and beach nourishment are effective as measures for recovering a sandy beach. Although beach nourishment is effective in each case, cases 9 and 10, in which breakwaters 2 and 3 are extended southward under the premise that beach nourishment is carried out at a rate of $2 \times 10^{4} \mathrm{~m}^{3} / \mathrm{yr}$, exhibit superiority. Case 9 , in which breakwaters Nos. 3 and 2 are extended southward by $100 \mathrm{~m}$ and $50 \mathrm{~m}$, respectively, with beach nourishment at a rate of $2 \times 10^{4} \mathrm{~m}^{3} / \mathrm{yr}$, is optimal for suppressing the shoreline recession north of breakwater No. 3 .

\section{CONCLUSIONS}

1. On the Shimizu coast, an L-groin was constructed to protect the Hagoromo-no-matsu sandy beach, where the sandy beach, pine trees and Mt. Fuji in the background form one of the famous picturesque scenes in Japan.

2. After the construction of the L-groin, the offshore discharge of fine sand, which was transported around the tip of the L-groin, was observed along with erosion downcoast of the L-groin, because of the existence of steep submarine canyons north of the L-groin.

3. The cause of offshore sand discharge is that the littoral zone was pushed offshore because of the extension of the groin so that it markedly protruded offshore. Fine sand with a median diameter of $0.2 \mathrm{~mm}$ is being discharged into the submarine canyons while gradually sliding down the offshore steep slope.

4. In contrast, coarser material mainly composed of gravel with the grain size $d_{50}$ ranging between 20 and $30 \mathrm{~mm}$ is being moved northward alongshore without being deposited into the offshore zone, and severe erosion occurs downcoast of breakwaters Nos. 1 and 2. In this area, although longshore sand transport of $7.5 \times 10^{4} \mathrm{~m}^{3} / \mathrm{yr}$ existed before 1998 , it has been reduced to $0.7 \times 10^{4} \mathrm{~m}^{3} / \mathrm{yr}$ since 1998. These beach changes were accurately predicted using the contour-line-change model.

5. A combination of the southward extension of the breakwater and beach nourishment is effective as a measure for recovering sandy beaches. The optimal case is that in which breakwaters Nos. 3 and 2 are extended southward by $100 \mathrm{~m}$ and $50 \mathrm{~m}$, respectively, with beach nourishment at a rate of $2 \times 10^{4} \mathrm{~m}^{3} / \mathrm{yr}$.

\section{REFERENCES}

Nishitani, M., T. Uda, M. Serizawa and T. Ishikawa. 2008. Measurement and prediction of deformation of conveyer belts carrying gravel and fine sand off Shimizu coast, Proc. 31st ICCE, 2570-2582.

Ozasa, H. and A. H. Brampton. 1980. Model for predicting the shoreline evolution of beaches backed by seawalls, Coastal Eng., 4, 47-64.

Sakai, K., T. Uda, M. Serizawa, T. Kumada and Y. Kanda. 2006. Model for predicting threedimensional sea bottom topography of statically stable beach, Proc. 30th ICCE, 3184-3196.

Serizawa, M., T. Uda, T. San-nami, K. Furuike and T. Kumada. 2003. Improvement of contour line change model in terms of stabilization mechanism of longitudinal profile, Coastal Sediments '03, $1-15$. 